
www.globaljournalseries.com, Email: info@globaljournalseries.com

\title{
ADOPTION OF DIFFERENT WEED MANAGEMENT TECHNIQUES AMONG COCOA FARMERS IN AKAMKPA LOCAL GOVERNMENT AREA, CROSS RIVER STATE, NIGERIA
}

\author{
ABOH, C. L. AND EFFIONG, J. B. \\ (Received 6 December 2018; Revision Accepted 14 February 2019)
}

\begin{abstract}
The study assessed weed management techniques among cocoa farmers in Akamkpa Local Government Area, Cross River State, Nigeria. Specifically, the objectives of the study were to assess the socio-economic characteristics of respondents in the study area; identify major weeds affecting cocoa farms, identify major techniques of weed management; ascertain the various indigenous weed management techniques employed by cocoa farmers in the study area. A random sampling technique was adopted in the selection of 120 respondents for the study. Also, descriptive statistics such as frequency counts, means and percentages, as well as inferential statistics such as chisquare model were used for analysis of the study objectives and the testing of study hypothesis respectively. Results of the study revealed that $(41.70 \%)$ had no formal education, $(37.50 \%)$ were aged above 50 years, $(58.30 \%)$ were married with children. Results of cocoa weeds predominant in the study area revealed that; Chromolaena odorata, Ageratim conyzoides, Pennisetum purpureum and Mimosa pudica were the major weeds that interfered with the cocoa crops in the study area at the percentage of $(82.50 \%),(74.20 \%),(63.30 \%)$ and $(48.30 \%)$ respectively. The results also showed that integrated weed management techniques were mostly used by cocoa farmers, but that indigenous weed management techniques such as slashing of weeds with machetes $(83.30 \%)$, hoe weeding $(75.00 \%)$ and hand pulling or hand rouging $(73.30 \%$ ) were also utilized by cocoa farmers for weed control in the study area. The study concluded that majority of the respondents were relatively young with very little or no formal education, limited access to large farmlands for cocoa production, earned less than N100,000 per annum from cocoa sales. The study, therefore, recommended that extension services be provided to the cocoa farmers to facilitate training and education on basic scientific weed and pest management techniques; that the land tenure system of 1978 be reviewed to allow farmers access to large hectares of arable land for cocoa farming.
\end{abstract}

KEY WORDS: Weed Management, Techniques, Cocoa, Farmers, Akamkpa

\section{INTRODUCTION}

Nigeria has a history of rich agricultural development dating back to the precolonial era, the 1960s and the first Republic of 1960-1966 where regional agriculture with specialization in the cultivation of selected crops such as rubber, cocoa and oil palm in the various regions were practiced (Effiong and Aboh, 2018). The earnings from the agricultural sector were used in financing major developmental projects and programmes in the country, notable amongst many were the University of Lagos, the Obafemi Awolowo University lle-Ife, Osun State, the 26-storey cocoa house in Ibadan Oyo State and the Free Education Programme in the Western Region; all financed from the proceeds of cocoa by the then premier government (Ekong, 2010; Effiong and Effiong, 2015).

According to Edet (2015), in Nigeria, like most West African countries; cocoa, rubber, palm oil, groundnut, and cotton are the major export crops use for foreign earnings. However, cocoa ranks high among the export crops from many West African countries. Aigbekaen (2011), posited that agriculture contributes about $88 \%$ non oil foreign exchange earnings of Nigeria and that cocoa is one of the leading export crops, however, majority of the cocoa farms in Nigeria are small, fragmented holdings ( $<0.5$ hectares), owned by a large number of peasant farmers who often lack the foundation or livelihood resources (land and capital) for expansion or improvement of existing farms. Vos and Krasuss (2004), asserted that annual cocoa yield fluctuated over the years with a production peak at 298,000 tons in $1964 / 1965$ to about $110,000-150,000$ metric tonnes per annum after the Nigerian civil war of 1967-1970. Similarly, Effiong and Effiong (2015) reported that cocoa yield in Nigeria is currently stagnated at about 180,000 metric tonnes per annum compared to 300,000 metric tonnes per annum 50 years ago.

Generally, studies have identified several

ABOH, C. L., Department of Agricultural Extension and Rural Sociology. Faculty of Agriculture, Forestry and Wildlife Resources Management University of Calabar Calabar Cross River State, Nigeria.

EFFIONG, J. B., Department of Agricultural Extension and Rural Sociology. Faculty of Agriculture, Forestry and Wildlife Resources Management University of Calabar Calabar Cross River State, Nigeria. 
technical factors which have contributed to the dwindling cocoa production levels in Nigeria and other West African countries. Paramount among these are problems caused by weeds, pests and diseases which have resulted to estimated loss of 30-40 percent of global cocoa yield and productivity (Padi, Owosu and Kumah, 2003).

Adesiji, Adekunle and Omokope (2007) identified weeds of cocoa to include Chromolaena odorata, Ageratim conyzides, Axonopus compressus, Rottboellia cochinchinensis as well as spine weeds.

Consequently, over the years, local farmers have in response developed and applied various strategies to diagnose, treat, manage and control pests, weeds and diseases in their cocoa farms. In their study, (Adesiji et al. 2007; Asante, 1997 and Al-Karabbieh, AlRimawi and Hunaiti, 2009) stated that small scale, resource - poor local farmers have acquired considerable wealth of environment related indigenous knowledge in harnessing and manipulating natural and socio-economic factors of cocoa production that have provided food for nearly half the world. They observed that the indigenous knowledge practices are environmentally friendly causing less harm to human and animal health, to habitats and the ecosystem in general but argued that synthetic agro-chemicals are better and more productive than the indigenous knowledge practices (IKP's). Aigbekaen (2011); Aneani, Anchirinah, Owuse-Ansah and Asamoah (2012); Akpabio (2005) reported that Cocoa Research Institute of Nigeria (CRIN) established in 1964 with the main objective of identifying the ecology and methods of controlling weeds as well as diseases affecting her mandate of research into the genetic improvement and production of cocoa, cashew, kola, tea and coffee has developed scientific technologies for improved cocoa productivities in Nigeria but their adoption and utilization by local farmers have been very low leading to low production level.

\section{Research methodology}

The study was conducted in Akamkpa Local Government Area of Cross River State, Nigeria, with headquarters located in Akamkpa. Akamkpa Local Government Area has an approximate land area of about $2,032 \mathrm{~km}^{2}$ and it is bounded in the south by Odukpani Local Government Area, in the North by Etung and Yakurr Local Government Areas, in the East by Akpabuyo Local Government Area and the Republic of Cameroon and in the West by Biase Local Government Area. Akamkpa Local Government Area is located between latitudes $5^{\circ} 001$ and $5^{\circ} 481$ North of the Equator and between longitude $08^{\circ} 001$ East of the Greenwich Meridian. The inhabitants of Akamkpa are predominantly Ejaham people and some other minorities that speak Efik and Dissang-lyong. Akamkpa is located within the rainforest zone of Cross River State with annual rainfall of between $2500 \mathrm{~mm}-3050 \mathrm{~mm}$ per annum. The dry season is from November to February and the rainy season is from March to October with annual mean temperature of $26^{\circ} \mathrm{C}$ (Atop, 2016). Cocoa is the major cash crop produced in agrarian communities along the Oban corridor of the Cross River tropical forest and the economy of the people majorly depends on the annual cocoa sales in the area. Initial intercropping or mixed cropping of cocoa with plantain, cocoyam, cassava, banana, yam and maize is commonly practiced.

Data for the study were obtained from primary (structured questionnaire) and secondary (textbooks, journals and internet, services) sources. The study population consisted of all registered cocoa farmers in the cocoa producing communities in Akamkpa Local Government Area of Cross River State. A random sampling technique was adopted in selecting the sample for the study. The list of registered cocoa farmers in the local government area was obtained from Cross River State Ministry of Agriculture. From the list, 905 farmers who were unevenly distributed across the 20 communities were identified. The registered population in each community (stratum was proportionately sampled by drawing $15 \%$ of the population with each stratum having the same sampling fraction. A Sample size of 120 cocoa farmers was ultimately selected from the 20 communities and administered questionnaires to elicit data used for the study. The study objectives were analyzed using descriptive statistics such as frequency counts and percentages, while the study hypothesis was analysed using inferential statistics (chi-square model).

\section{Results and Discussion}

The results of the socio-economic characteristics of the respondents (Table 1) revealed that majority $(35.80 \%)$ were within the age range of $31-$ 40 years. This implies that this group of farmers in the study area were young and energetic. Young people are most likely to understand basic weed management principles. Furthermore, $37.50 \%$ were within $41-50$ years and $18.30 \%$ were above 50 years of age, also implying that cocoa production activities in the study area were dominated by young farmers from 40-50 years old. Farmers within the age bracket of 41-50 years are generally viewed as the most active labour force in the agricultural sector of the Nigerian economy capable of enhancing yields and productivities of crops through the adoption and use of scientific production techniques (Bamigboye, 2010).

The result also showed that $29.20 \%$ of the respondents were single, $58.30 \%$ were married, $8.30 \%$ were divorced and $4.20 \%$ were widowed, implying that majority of the respondents $58.30 \%$ in the study area were married and had children. Also, $41.70 \%$ of the respondents never had formal education, $16.70 \%$ obtained primary education, $33.30 \%$ had secondary education and $8.30 \%$ attended tertiary institutions such as Colleges of Education and Agriculture, Polytechnics and Universities. The implication is that, nearly half of the cocoa farmers in the study area were illiterate and this could likely affect the level of innovation adoption and application of agro-chemicals such as herbicides and fungicides. Ekong (2010) reported that there is a significant relationship between literacy and adoption of agricultural innovations and improved farming techniques. Results in Table 1 also indicated that majority of the respondents $81.70 \%$ earned below $\mathrm{N} 100,000$ per annum, $11.70 \%$ earned between N100,000-N200,000 annually, while $6.60 \%$ earned above N200,000 per annum from cocoa farming in the study area. This result could be due to the low level of adoption of improved weed control methods in the study area. 
Table 1: Distribution of respondents based on socio-economic characteristics

\begin{tabular}{lll}
\hline Variable & Frequency & Percentage \\
\hline Age & 10 & \\
a. 30 & 43 & 8.30 \\
b. $31-40$ & 45 & 35.80 \\
c. $41-50$ & 22 & 37.50 \\
d. Above 50 & 120 & 18.30 \\
Total & & 100.00 \\
Marital Status & 35 & \\
a. Single & 70 & 29.20 \\
b. Married & 10 & 58.30 \\
c. Divorced & 5 & 8.30 \\
d. Widowed & 120 & 4.20 \\
Total & & 100.00 \\
Levels of Education & 50 & \\
a. Never been to school & 20 & 41.70 \\
b. Primary school & 40 & 33.30 \\
c. Secondary school & 10 & 16.70 \\
d. Tertiary Education & 120 & 8.30 \\
Total & & 100.00 \\
Size of cocoa farm & 70 & \\
a. <1.0 ha & 44 & 58.30 \\
b. $2.0-3.0$ ha & 6 & 36.70 \\
c. $4.0-5.0$ ha & - & 50.00 \\
d. 6.0 ha and above & 120 & - \\
Total & & 100.00 \\
Annual Income (N) & 98 & 81.70 \\
a. <100,000 & 14 & 11.70 \\
b. $100,000-200,000$ & 8 & 6.60 \\
c. Above 200,000 & $\mathbf{1 2 0}$ & $\mathbf{1 0 0 . 0 0}$ \\
Total & &
\end{tabular}

Source: Field Survey, 2017

Results of the distribution of respondents based on cocoa weeds identified are presented in Table 2. The Table revealed that Chromlaena odorata $82.50 \%$, Ageratim conyzoides $74.20 \%$, Pennisetum purpureum $63.30 \%$ and Mimosa pudica $48.30 \%$ were the major dominant cocoa weeds identified in the study area and were ranked $\left(1^{\text {st }}, 2^{\text {nd }}, 3^{\text {rd }}\right.$ and $\left.4^{\text {th }}\right)$ respectively while Axonopus compressus $20.80 \%$, Tribulus terrestris $36.70 \%$, Rottboellia cochinchinensis $39.20 \%$ and
Imperata cylindrica $43.30 \%$ were identified as the least weeds that affected cocoa productivity in the study area and were ranked $\left(8^{\text {th }}, 7^{\text {th }}, 6^{\text {th }}\right.$ and $\left.5^{\text {th }}\right)$ respectively. This result corroborates the findings of Padi, Owosu and Kumah (2003) who reported that weeds competition with cocoa plants contributes to the dwindling cocoa productivity/yield levels in Nigeria and other West African countries such as Ghana and cote d' ivoire.

Table 2: Results of the distribution of respondents based on cocoa weeds identified

\begin{tabular}{llllll}
\hline Scientific name & Common weeds & $\begin{array}{l}\text { Local name } \\
\text { (Ejaham) }\end{array}$ & Frequency & Percentage & Rank \\
\hline Ageratim conyzoides & Goat weed & Nsonekwi & 89 & 74.2 & $2^{\text {nd }}$ \\
Tribulus terrestris & Spine weed & Agangase & 44 & 36.7 & $7^{\text {th }}$ \\
Mimosa pudica & Mimosa spp. & Mabuindip & 58 & 48.3 & $4^{\text {th }}$ \\
Imperata cylindrica & Spear grass & Takruja & 52 & 43.3 & $5^{\text {th }}$ \\
Chromolaena odorata & Eupatorum odoratum & Obiaratu & 99 & 82.5 & $1^{\text {st }}$ \\
Pennisetum purpureum & Elephant grass & Aruaya & 76 & 63.3 & $3^{\text {rd }}$ \\
Rottboellia cochinchinensis & Itching grass & Asabe & 47 & 39.2 & $6^{\text {th }}$ \\
Axonopus compressus & Carpet grass & Irighinsi & 25 & 20.8 & $8^{\text {th }}$ \\
\hline
\end{tabular}

Source: Field Survey, 2017

Table 3, shows that majority $56.60 \%$ uses integrated weed management techniques by combining both indigenous and conventional weed management techniques for weed management in the study area while $26.70 \%$ uses indigenous techniques and $16.70 \%$ uses conventional techniques of weeds management respectively in the study area. Local farmers are used to both scientific and indigenous weed management techniques in the study area. Padi et al. (2003) observed a trend where farmers rely on indigenous knowledge 
Table 3: Result of the distribution of respondents based on techniques of weed management

\begin{tabular}{lll}
\hline Management Technique & Frequency & Percentage \\
\hline Indigenous & 32 & 26.70 \\
Conventional & 20 & 16.70 \\
Conventional/indigenous techniques & 68 & 56.60 \\
Total & $\mathbf{1 2 0}$ & $\mathbf{1 0 0 . 0 0}$ \\
\hline
\end{tabular}

Source: Field Survey, 2017.

The results in Table 4 shows the indigenous weed management techniques utilized by cocoa farmers in the study area. The table revealed that slashing of weeds with machete $83.30 \%$, use of hoe $75.00 \%$, hand pulling or rouging of weeds $73.30 \%$ were the major indigenous weed management techniques utilized by cocoa farmers in the study area and were ranked $\left(1^{\text {st }}, 2^{\text {nd }}, 3^{\text {rd }}\right)$ respectively while mulching practices $52.50 \%$, cover cropping $37.50 \%$ and tillage/burying in the soil $15.00 \%$, were also utilized by cocoa farmers and ranked $\left(4^{\text {th }}, 5^{\text {th }}\right.$ and $6^{\text {th }}$ ) respectively. However, sole cropping and grazing by animals were not used by the farmers as an indigenous weed management techniques. The study showed that all the respondents farmers controlled weeds through field slashing.

Table 4: Distribution of indigenous weed management techniques employed by cocoa farmers

\begin{tabular}{llll}
\hline Indigenous techniques & Frequency & Percentage & Ranks \\
\hline Slashing of weeds & 100 & 83.3 & $1^{\text {st }}$ \\
Burning of weeds & - & - & - \\
Hand pulling of weed & 88 & 73.3 & $3^{\text {rd }}$ \\
Use of hoe & 90 & 75.0 & $2^{\text {nd }}$ \\
Use of local mixture & - & - & - \\
Mulching & 63 & 52.5 & $4^{\text {th }}$ \\
Tillage and burying & 18 & 15.0 & $6^{\text {th }}$ \\
Covercropping & 45 & 37.5 & $5^{\text {th }}$ \\
Sole cropping & - & - & - \\
Grazing by animals & - & - & - \\
\hline
\end{tabular}

Source: Field Survey, 2017.

Results of the distribution of respondents based on conventional weeds management technique identified are presented in Table 5 . The Table revealed that majority of the respondents $38.33 \%$ used herbicides and $27.50 \%$ used mulching methods to control weeds in their cocoa farms. Also, $22.50 \%$ used cover cropping method, while $11.67 \%$ used machines to control weeds in their cocoa farms in the study area. The study agrees with Doss (2003) that majority of the cocoa farmers in Nigeria are small holders who employ conventional weed management techniques in controlling weeds in their farms. This is why the adoption of conventional techniques of weed management is still an issue of concern.

Table 5: Result of the distribution of respondents based on conventional weed management technique

\begin{tabular}{|l|l|l|}
\hline Conventional management technique & Frequency & percentage \\
\hline Use of herbicides & 46 & 38.33 \\
Mulching & 33 & 27.50 \\
Covercropping & 27 & 22.50 \\
Machines & 14 & 11.67 \\
\hline Total & $\mathbf{1 2 0}$ & $\mathbf{1 0 0 . 0 0}$ \\
\hline
\end{tabular}

Source: Field Survey, 2017

\section{Research hypothesis}

$\mathrm{Ho}_{1}$ : There is no significant relationship between the age of cocoa farmers and the use of selected indigenous and scientific weed management techniques in the study area.

Results from table 5 revealed that all the computed $\mathrm{X}^{2}$ values of hoe weeding (3.65), slashing (0.229), cover cropping $(0.17)$, integrated management (1.65) and herbicide $(0.11)$ were lesser than the tabulated $X^{2}$ values (5.99) at $(5 \%)$ significance level, hence, the null hypothesis was accepted and the alternative hypothesis rejected, stating that there is no significant relationship between the farmers age and the use of indigenous and scientific weed management techniques. This result contradicts findings of Adesiji et al., (2007) who reported that in Ogun State, SouthWestern Nigeria, age was found to have positively influence the use of indigenous methods of weed management of cocoa farmers. 
Table 6: Distribution of respondents based on the relationship between their ages and the use of selected weed management techniques

\begin{tabular}{|c|c|c|c|c|c|c|c|}
\hline Technique/age & Use & $\begin{array}{l}\text { Young } \\
\text { (31-40yrs) }\end{array}$ & $\begin{array}{l}\text { Middle } \\
\text { (41-50yrs) }\end{array}$ & $\begin{array}{l}\text { Old } \\
\text { (50yrs \&above) }\end{array}$ & Total & $\begin{array}{l}\text { Chi-square } \\
\left(X^{2}\right)\end{array}$ & $\begin{array}{l}\text { Level of } \\
\text { significance }\end{array}$ \\
\hline \multirow[t]{2}{*}{ Hoe weeding } & Used & $45(41.3)$ & $30(27.0)$ & $15(14.3)$ & 90 & 3.65 & NS \\
\hline & Not used & $10(13.8)$ & $6(9.0)$ & $4(4.75)$ & 30 & & \\
\hline \multirow[t]{2}{*}{ Slashing } & Used & $35(34.2)$ & $36(35.0)$ & $29(29.2)$ & 100 & 0.299 & NS \\
\hline & Not used & $6(6.83)$ & $8(7.0)$ & $6(5.83)$ & 20 & & \\
\hline \multirow[t]{2}{*}{ Covercropping } & Used & $16(13.1)$ & $13(20.3)$ & $16(13.5)$ & 45 & 0.17 & NS \\
\hline & Not used & $21(23.1)$ & $40(33.8)$ & $20(22.5)$ & 75 & & \\
\hline \multirow{4}{*}{$\begin{array}{l}\text { Use of integrated } \\
\text { management } \\
\text { Use of herbicides }\end{array}$} & Used & $29(25.7)$ & $16(17.1)$ & $12(14.3)$ & 57 & 1.65 & NS \\
\hline & Not used & $25(28.4)$ & $20(18.9)$ & $18(15.8)$ & 63 & & \\
\hline & Used & $14(15.2)$ & $12(10.3)$ & $8(8.2)$ & 34 & 0.11 & NS \\
\hline & Not used & $39(38.0)$ & $26(27.2)$ & $21(20.8)$ & 86 & & \\
\hline
\end{tabular}

Source: Field Survey, 2017

$X^{2}$ tab 5\% DF $2=5.99$

\section{CONCLUSION}

Results of the socio-economic characteristics of the respondents revealed that majority $(58.30 \%)$ were married, $(37.80 \%)$ had less than 1.0 hectare of farmland. Major weeds that militated against cocoa production in the study area were Chromolaena odorata, Ageratim conyzoides, Pennisetum purpureum and Mimosa pudica. Also, majority of the respondents utilized integrated weed management techniques for weed management in the study area. The study also concluded that there was no significant relationship between the age of cocoa farmers and the use of selected indigenous and scientific weed management techniques as all the computed values $\left(\mathrm{X}^{2}\right)$ such as hoe weeding, slashing, covercropping and herbicide were lesser than the tabulated $\left(X^{2}\right)$ value $(5.99)$ at $(5 \%)$ significance level; hence, the null hypothesis was accepted and the alternative hypothesis rejected, stating that there was no significant relationship between the age of cocoa farmers and the use of selected indigenous and scientific weed management techniques in the study area.

\section{RECOMMENDATIONS}

The study recommended that;

1. Extension services should be funded with logistic supports, to enable it perform its primarily duty of educating local farmers and disseminating innovations on improved scientific weed management technologies.

2. Human capital development through qualitative education and training on scientific weed management technologies should be provided to the farmers since nearly half of the respondents were illiterate. Generally, there is significant relationship between literacy and innovation adoption.

3. The study also recommended the use of integrated weed management technologies for increased yield/productivity and cost effectiveness.

\section{REFERENCES}

Adesiji, G. B., Adekunle, A. and Omokope, D. F., 2007. Indigenous control practices of pests and diseases of cocoa by farmers in Osun and Ekiti
States of Nigeria. Agricultural Journal 2(6):662666 .

Aigbekaen, E. O., 2011. Evaluation of some factors affecting the yield of cocoa in the cocoa research institute of Nigeria. Journal of Tree Crop Research, 4(2):66-68

Akpabio, I. A., 2005. Human Agriculture: Social Themes in Agricultural Development. Abeam Publishing

Company Unit G72 Ewet Housing Estate, Uyo, Akwa Ibom State, Nigeria. pp.13-14.

Al-Karabbieh, E. K., Al-Rimawi, A. S. and Hunaiti, D. A., 2009. Logit models for identifying the factor that influences the adoption of barley production technologies in low rainfall areas. Jordan. Journal of Agricultural Sciences, 5(3): 251-265.

Aneani, F., Anchirinah, V. M., Owosu-Ansah, F. and Asamoah 2012. Adoption of some cocoa production technologies by cocoa farmers in Ghana. Journal of Sustainable Agriculture Research, 1(1): 40-41.

Asante, E. G., 1997. The economic relevance of plant disease and pest management in the Ghana cocoa industry. Proc. $1^{\text {st }}$ Int. Cocoa pests and diseases seminar, 6-10 Nov., 1995, Accra, Ghana: 288-299.

Atop, F. O., 2016. Use of weed and pest management techniques by cocoa farmers in Cross River State, Nigeria. Unpublished M.Sc thesis submitted to the Department of Agricultural Economics and Extension, Faculty of Agriculture, University of Calabar, Calabar.

Bamigboye, E. O., 2010. Factors associated with the utilization of indigenous knowledge system for rice production by farmers in Ekiti State, Nigeria. An Unpublished M.Sc thesis submitted to the department of Agricultural Economics and Extension (LAUTECH), Ogbomosho, Lagos State, Nigeria. pp.20-24. 
Doss, C R., 2003. Understanding farm technology adoption. Lessons learned from CIMMYT'S Micro Surveys in Eastern Africa. CIMMYT Economics Working Paper No.03-07. Mexico City CIMMTY

Edet, E. O., 2015. Economic impact of climate change on selected export crops in Nigteria 1970-2012. An unpublished Ph.D thesis submitted to the Department of Agricultural Economics, University of Calabar, Cross River State, Nigeria, pp.2-3.

Effiong, J. B. and Aboh, C. L., 2018. Rubber production technologies and the related socio-economic environments. Global Journal of Agricultural Sciences, 17(1): 15-22.

Effiong, J. B. and Effiong, G. B., 2015. Adoption of improved rubber production technologies by farmers in Akwa lbom State, Nigeria. Global Journal of Agricultural Science, Nigeria. 14(1) 2015: 29-43.
Ekong, E. E., 2010. Rural Sociology: An introduction and analysis of rural Nigeria $3^{\text {rd }}$ edition. Dove Educational Publishers, 80 Wellinton Bassey Way, Uyo, Nigeria.

Padi, B., Owosu, G. K. and Kumah, N. R., 2003. A record of Desplatsia dewevnei De wild and Th. Diu Tiliales: Tiliciceae. As an alternative and potential breeding host plant for the cocoa mired schlbergella singulars Hagl. Proceeding of $12^{\text {th }}$ International Cocoa Research Conference, Salvater, Bahia, Brazil, pp.25-37.

Vos, J. M. and Krasuss, U., 2004. Working with farmers. cocoa futures. A source book of some important issues controlling cocoa industry. Flood J., Morphy R. Eds Feriva, S. A. Cali Coloumbia $\mathrm{CABI}$ commodities. An initiatives of $\mathrm{CABI}$ Bioscience. Colombia The Commodities Press, (12): 141-149. 